\title{
A Study on Risk Prevention for Online P2P Lending Platforms in China
}

\author{
Yaqiong Pan \\ College of Management \\ Wuhan University of Science and Technology \\ Hubei, China \\ 445973958@qq.com
}

\author{
Jun Gao \\ College of Management \\ Wuhan University of Science and Technology \\ Hubei, China \\ 1364365868@qq.com
}

\begin{abstract}
The present study was designed to study the risks of online P2P lending platforms. The aim of this study was to analysis the problem of online P2P lending platforms in theory, and then to propose some suggestion for the development of lending platforms. We provided a new perspective and context to study the risks of P2P lending platforms, based on different types of industries, i.e. private operation sector, bank sector, listed company sector, state-owned asset sector, venture capital sector. We also described the conceptual background and development of online P2P lending platforms in China. Then, the risks are listed from two sides in the industry of online P2P lending. At last, targeted suggestions are proposed for the development of online P2P lending. To eliminate these obstacles of the healthy and sustainable development of online P2P lending, we find that, it can be set out from two aspects of internal and external.
\end{abstract}

Keywords-Online P2P lending; risk analysis; improving measures

\section{INTRODUCTION}

Online P2P lending is a kind of lending mode in which individual investors directly provide an uncertain amount of loans to personal borrowers without the intervention of banks and other intermediary organs. [1]As an important branch of internet financial products, online $\mathrm{P} 2 \mathrm{P}$ lending has become the focus of all sectors of the society in recent years. Online P2P lending breaks through the usual state of traditional lending in which the bank serves as the intermediary organ. In this way, the capital chain of both parties is shortened, and the problem of financing difficulty is effectively relieved for Chinese small and medium enterprises. On the other hand, since the entry threshold of online P2P lending platforms is low, more and more individuals start to invest on online $\mathrm{P} 2 \mathrm{P}$ lending platforms. [2] However, with the rapid development of online P2P lending, a series of bankruptcy and fleeing problems have appeared in recent years. These risks bring about the crisis for the development of internet finance. [3]Thus, it is very crucial to effectively evaluate and control the risks as well as establish rational risk prevention and control mechanism for $\mathrm{P} 2 \mathrm{P}$ platforms.

In this paper, relevant indexes of online P2P lending platforms are studied. Besides, contrastive analysis of defective platforms and good lending platforms is carried out. Finally, targeted suggestions are put forward for the development of online $\mathrm{P} 2 \mathrm{P}$ lending platforms from the perspectives of macroscopic supervision and internal control.

\section{DEVELOPMENT STATUS OF ONLINE P2P LENDING PLATFORMS IN CHINA}

First, confirm that you have the correct template for your paper size. This template has been tailored for output on the A4 paper size. Since the first online P2P lending platform ppdai was founded in 2007, online P2P lending platforms have grown rapidly in China like mushrooms after rain. At present, relatively mature online $\mathrm{P} 2 \mathrm{P}$ lending platforms in China include Renrendai, Hongling Capital, CreditEase and so on. [4][5]The statistical data of WDZJ show that both the quantity and transaction amount of $\mathrm{P} 2 \mathrm{P}$ platforms have increased sharply in recent years. Seeing from the number of $\mathrm{P} 2 \mathrm{P}$ platforms, the growth rate in 2014 was as high as 253\%. By the end of February 2017, there had been more than 5800 P2P platforms nationwide. Seeing from the transaction amount, by the end of February 2017, the total transaction amount of online P2P lending platforms had reached 340.571 billion nationwide.

With the rapid development, the risks that online $\mathrm{P} 2 \mathrm{P}$ lending performs are faced with also increase every day. For both China and foreign countries, the risks that online P2P lending performs are faced with deserve our vigilance. At abroad, even if quite mature online P2P lending performs such as Prosper and Lending Club are also confronted with numerous risks including credit risk. In China, there are many defective platforms, and the investors of online $\mathrm{P} 2 \mathrm{P}$ lending platforms are mostly individual investors whose risk recognition and bearing capacity are weak. Hence, risk accumulation is increasingly worthy of attention. [6]The number of defective platforms in recent years is shown in Table 1. 
TABLE I.

SITUATIONS OF DEFECTIVE PROBLEMS

\begin{tabular}{|c|c|c|c|c|c|}
\hline Year & No. & $\begin{array}{c}\text { Withdrawal } \\
\text { difficulty }\end{array}$ & $\begin{array}{c}\text { Economic } \\
\text { detector } \\
\text { intervention }\end{array}$ & $\begin{array}{c}\text { Suspension of } \\
\text { business }\end{array}$ & Fleeing \\
\hline 2013 & 74 & 62 & 0 & 6 & 6 \\
\hline 2014 & 277 & 118 & 4 & 33 & 122 \\
\hline 2015 & 1206 & 283 & 12 & 350 & 561 \\
\hline 2016 & 1851 & 177 & 6 & 1247 & 421 \\
\hline
\end{tabular}

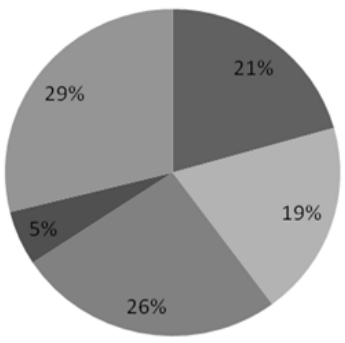

- Private operation sector

= Bank sector

= Listed company sector

- State-owned asset sector

Eventure capital sector

Fig. 1. Trading volume distribution of operation pltaforms

According to Table 1, the number of defective platforms in 2014 is 4.74 times of that in 2013, and the number of defective platforms in 2015 is 4.35 times of that in 2014. By the end of 2016, the number of defective platforms had reached 1851. Besides, $67.37 \%$ of them suspend business, and $22.74 \%$ of them run away. The above data indicate that the credit risk of online P2P lending platforms has been very serious. Fig.1 shows the classification of industries where defective platforms are. It is divided by trading volume and industry of operation platforms. We can find that the trading volume of Venture capital sector is most, and Private operation sector's is the third. In addition, We can see from Table 2 that the accumulative number of defective platforms in private operation sector accounts for $99.32 \%$ of the total amount. This indicates that in the popular internet finance, privatelyoperated P2P platforms have the highest risks. It most probably that the operating platform in Private operation sector is lack of reasonable regulation in the process of management .

TABLE II. TYPES OF DEFECTIVE OPERATING PLATFORMS

\begin{tabular}{|c|c|c|c|}
\hline Type & $\begin{array}{c}\text { Trading } \\
\text { volume } \\
(100 \text { million })\end{array}$ & $\begin{array}{c}\text { Number of } \\
\text { operation } \\
\text { platforms }\end{array}$ & $\begin{array}{c}\text { Accumulative } \\
\text { number of } \\
\text { defective platforms }\end{array}$ \\
\hline $\begin{array}{c}\text { Private operation } \\
\text { sector }\end{array}$ & 701.27 & 1954 & 3531 \\
\hline Bank sector & 657.16 & 15 & 3 \\
\hline Listed company sector & 879.51 & 116 & 16 \\
\hline $\begin{array}{c}\text { State-owned asset } \\
\text { sector }\end{array}$ & 183.97 & 171 & 1 \\
\hline Venture capital sector & 983.80 & 137 & \\
\hline
\end{tabular}

\section{MAIN RISKS THAT ONLINE P2P LENDING PLATFORMS ARE} FACED WITH

\section{A. Internal risks}

Generally, investors decide their investments after browsing the information provided by online P2P lending platforms. After the investors purchase the creditor's rights, their funds are mostly transferred to online lending platform accounts first, and then the online lending platform will transfer the funds into the accounts of borrowers. When the online lending platform as the intermediate account saves the funds, the moral hazard of lending platform will be tested. According to Table 1, the number of platforms which went bankrupt due to fleeing in 2015 accounts for $46.52 \%$ of total number of defective platforms, close to a half of total number of defective platforms.

Secondly, due to information asymmetry between lenders and borrowers, some online P2P lending platforms increase capital flow, falsely disclose the financing scale, financing source and the use of funds and exaggerate the trading volume in order to attract more investors. These violations intangibly increase the investment risks of individual investors and seriously threaten sustainable development of platforms.[7]

Finally, relative to developed countries, many online P2P lending platforms in China fail to provide all-round lending information indexes. Emkter et al. consider that credit score, debt-to-income ratio, FICO score and cyclic utilization rate significantly influence loan default behaviors. [8]Few online lending platforms in China provide debt-to-income ratio and cyclic utilization rate etc. Thus, the investment risks of investors increase.

\section{B. External risks}

Since online P2P lending in China develops later than western countries, internet financial system of China is still not sound enough. [9]Moreover, significant differences exist between Chinese and western cultures. The information of bank reference center in China mainly serves for banking system, and it is very difficult for other industries to contact these data, let alone online $\mathrm{P} 2 \mathrm{P}$ lending platforms. Thus, it is hard for online lending platforms to distinguish the information provided by borrowers during auditing and screening borrowers. This may easily result in potential default risks. Besides, the number of online P2P lending platforms is large in China, and the quality is uneven. It is hard to form information resources sharing.

Over the years, the financial system has been leaded by the government in China. All institutions in this system establish their norms on the basis of policies of the government. As a consequence, the emerging industry is refused to enter the financial system. At present, online P2P lending platforms in China are still in the state of no access threshold, no industrial standard and no supervision organization. Compared with traditional finance, the type and operation mode of internet finance are updated continuously. The scope and environment also keep extending and changing. As well, the supervision objects and subjects far surpass the scope of traditional supervision system. Financial supervision standpoint of 
traditional finance is not applicable to internet financial environment. Internet finance is more complex than traditional finance in terms of industrial crossing and mixing. [10]Thus, brand-new supervision subject and supervision standpoint are required to improve supervision efficiency and eliminate the vacuum zone of supervision.

\section{COUNTERMEASURES AND SUGGESTIONS ON IMPROVING RISK CONTROL SYSTEM OF ONLINE P2P LENDING PLATFORMS IN CHINA}

\section{A. To establish market access mechanism and industry exit mechanism}

The entry threshold of online P2P lending platforms is low, so individual investors mainly invest on online P2P lending platforms. The establishment of market access mechanism can effectively reduce fleeing risk of online lending platforms and investors' investment risks. In the aspect of market access, it is required to start from relevant policies. Except the operation qualification and ability of platforms, the operation quality of platform founders also shall be audited. Platform founders shall prepare the specified funds as the guarantee, and their access threshold shall be limited. Besides, their corresponding rights and obligations should be stipulated. It is necessary to promote the development of P2P industry according to the specified supervision objective. Market access of P2P lending platforms may be registered for future reference.

Secondly, the P2P platform is generally an intermediary agency, and its clients include borrowers and investors who do not know each other and transact via the platform. Once the platform is closed down, the bond between borrowers and investors will be inevitably broken, and the fund risk will occur. Therefore, it is especially important to establish platform exit mechanism and protect investors' rights and interests. Market access and exit rules of P2P platforms should be specified to prevent $\mathrm{P} 2 \mathrm{P}$ platforms from engaging in absorbing deposits, issuing loans and entrusting fund management.

\section{B. To establish risk reserve system and fund security supervision system}

The risk reserve is extracted from the platform profit according to certain proportion. When the platform goes wrong and involves normal use, the principal of investors will be compensated in advance to protect investors' interests. The setup of risk reserve lowers the risks triggered by object problem or operation problem. The platform will not further deteriorate due to capital chain rupture. This protects investors' interests and can solve risk sharing obligation and responsibility division problem.

In addition, online P2P lending platforms as information intermediary platforms should not embezzle investors' funds at will. Strict fund management system should be established to entirely isolate clients' funds and investors' funds so as to better protect clients' funds. The establishment of isolation system can make the platform funds get better management. The platforms need to entrust the risk reserve to a third-party financial organization so as to avoid fund embezzlement and hidden risks.

\section{To accelerate supervision system construction and information disclosure supervision}

In the aspect of supervision system construction, the upper-level supervision system which involves People's Bank of China, China Banking Regulatory Commission and local financial supervision departments should be established, and relevant laws and regulations on online P2P lending should be formulated to specify the corporate nature, business cope and industrial standards of online P2P lending platforms. In addition to theses, the middle-level supervision system which consists of lenders, platforms and borrowers should be established.

Furthermore, P2P industry should disclose information at a regular interval, increase information disclosure scope and improve information transparency in order to avoid public interest loss caused by information asymmetry and incompletion. On the one hand, online P2P lending platforms should disclose their management and operation information to the market; on the other hand, they should warn investors of relevant risks. The supervisory management law should stipulate that $\mathrm{P} 2 \mathrm{P}$ platforms shall publish the annual report and especially bad debt ratio of platforms so that investors and supervision organizations can know the risks of P2P lending platforms. Meanwhile, investors' interests can be ensured, and the $\mathrm{P} 2 \mathrm{P}$ platforms with high bad debt ratio can be rectified in time.

\section{To improve nationwide credit reference system}

We can find that some western countries where online P2P lending platforms develop well have a set of good credit evaluation mechanism and have establish very sound credit reference system. The information of credit reference system can be gained by qualified financial organizations to evaluate their clients. However in China, credit records only exist among banks, and credit records of large banks cannot be shared. As a result, credit reference system cannot be effectively established in China, which is adverse to the development of financial institutions and affects the improvement of financial system. Hence, the establishment of a set of sound credit reference system contributes to lowering transaction risks of online $\mathrm{P} 2 \mathrm{P}$ lending platforms.

\section{CONCLUSIONS}

As an important branch of internet financial products, online P2P lending has been an important topic for different industries. It has been valued by all sectors of the society in recent years. Exploring the risks of operating platform from different perspective contributes to studying online $\mathrm{P} 2 \mathrm{P}$ lending. Only minimizing the potential risks of online P2P lending platform, people can enjoy the convenience brought by the P2P loans. 


\section{REFERENCES}

[1] Li Bo, Dong Liang. Mode and Development of Internet Finance [J]. China Finance, 201 3(10).

[2] Sonenshein S, Herzenstein M, Dholakia U M. How accounts shape lending decisions through fostering perceived trustworthiness[J]. Organizational Behavior \& Human Decision Processes, 2011, 115(1):69-84.

[3] Tu Jing, Tong Zeping. Risk Reserve Fund, Loan Overdue and Running on P2P Platform [J]. Financial Theory \& Practice, 2016(2):27-31.

[4] Dong Jiafeng. Risks and Countermeasures of Chinese Offline P2P Lending Platforms - Case Study of CreditEase [J]. Securities \& Futures of China, 2013(7X):84-85.

[5] Nie Tao. Study on Mode and Risk of Chinese Online P2P lending Platforms [J]. Modern Business Trade Industry, 2014(6):166-167.
[6] Chen Dongyu, Lin Zhangxi. Dual Trust in Online Lending and Its Influencing Mechanism on Credit Will [D]. Journal of Fuzhou University, 2013 (1).

[7] Wang Huijuan, Liao Li. Chinese P2P Platform's Credit Authentication Mechanism Research-Evidence from Renrendai [J]. China Industrial Economics, 2014(4):136-147.

[8] Riza Emekter, Yanbin Tu, Benjamas Jirasakuldech, Min Lu. Evaluating credit risk and loan performance in online Peer-to-Peer (P2P) lending [J] Applied Economics, 2015, 47(1):

[9] Yin Haiyuan, Wang Panpan. The Current Supervisory Situation and System Formation of China's Internet Finance [J]. Finance \& Economics, 2015(9):12-24.

[10] Zheng Qiao. On Legal Risks and Countermeasures of Online P2P Lending Platforms [J]. Science \& Technology, Economy and Market, 2016(5):159-160. 